\title{
Life Satisfaction and mobility: Their associations with career attitudes, and health-related factors among postgraduates having studied in universities intra EU and outside EU
}

\author{
Angela Odero, Louis Chauvel, Anne Hartung, Etienne le Bihan and Michèle Baumann* (1)
}

\begin{abstract}
Background: University postgraduates' mobility towards, and outside the EU is continuously increasing, creating a competitive context in which maintaining a high life satisfaction (LS) is a public health challenge. However, the relationship between LS and its determinants among this population are under-documented. Our aims were to measure LS indicators of mobile postgraduates (Intra EU: Who pursue part of their studies in Europe; Outside EU: Who study outside of Europe) versus non-mobile (pursue their studies in Luxembourg), and to analyze the associations between LS and career attitudes, socioeconomic characteristics, and health-related factors for each group.

Method: Six hundred and sixty-four (644) students obtained financial aid from the Luxembourgish government independent of their family's socioeconomic situation. Contacted by post, they completed an online questionnaire. Analyses included a multiple linear regression model in which only significant relationships $(p<0.05)$ were used.

Results: Three groups were created: Mobile intra EU $(n=381)$, mobile outside EU $(n=43)$ and non-mobile $(n=66)$ postgraduates. Health satisfaction was positively linked to LS, in all groups. Among the mobile outside EU group, majority (63.2\%) were men and 57.9\% did not live alone - health was the only determinant which contributed to their LS. Among the mobile intra EU, majority (57.8\%) were women, and $64.3 \%$ not living alone. Autonomy and career adaptability attitudes were positively associated with their LS (b: 0.210 and 0.119 , respectively), whereas the worry factor was negatively (b: -0.153 and -0.159 ) associated. The non-mobile, were the oldest of the three groups. Majority (51.6\%) were women, and $93.7 \%$ did not live alone. Career optimism and planning attitudes were positively correlated to their LS (regression parameter estimates (b: 0.400 and 0.212 , respectively).

Conclusions: Attention should be devoted to the LS of local and cosmopolitan students, as it seems to be a relevant health indicator. Overall, the farther the mobility was, the higher the postgraduates' general LS (8.5/10) was; this indicator was higher than the LS indicator for the age group 25-34 years 7.53/10 (EU-28, in 2013). University' services could promote the development of career projects and the promotion of health to enhance postgraduates' LS. University policy makers need to ensure this for all students.
\end{abstract}

Keywords: Life satisfaction, Student mobility abroad, Postgraduates, Health satisfaction, Career attitudes, Cultural capital

\footnotetext{
* Correspondence: michele.baumann@uni.lu

Institute for Research on Socio-Economic Inequalities - axis Health

inequalities. Research unit INSIDE, University of Luxembourg, Belval Campus,

L-4366 Esch-sur-Alzette, Luxembourg
}

(c) The Author(s). 2020 Open Access This article is distributed under the terms of the Creative Commons Attribution 4.0 International License (http://creativecommons.org/licenses/by/4.0/), which permits unrestricted use, distribution, and reproduction in any medium, provided you give appropriate credit to the original author(s) and the source, provide a link to the Creative Commons license, and indicate if changes were made. The Creative Commons Public Domain Dedication waiver (http://creativecommons.org/publicdomain/zero/1.0/) applies to the data made available in this article, unless otherwise stated. 


\section{Background}

An increasing number of international students profit from the ease of mobility within and outside the EU. University mobility experience is a time to capitalize on personal abilities; hence students are likely to be driven by strategies linked to employability or by the prospect of an enriching experience abroad. However, mobility can also pose a risk to physical and mental functioning [1], and life satisfaction (LS) [2]. For instance, the experience of mobility abroad may produce protective (e.g. positive affect, optimism, happiness), or detrimental effects (e.g. anxiety, hostility, anger) [3]. This raises the question whether the level of LS, which represents the perceived degree of discrepancy between individual aspirations and achievements, and contentment $[4,5]$, differs between mobile intra EU and mobile outside EU. [Intra EU: Students who pursue part of their studies (example, Erasmus semester) in a European country, different from their home country; Outside EU: Students who pursue part of their studies (example, Erasmus global exchange) outside Europe].

Leaving home to live in another country and adjusting to a new social and cultural environment can increase the prevalence of social isolation, depression, and anxiety coupled with hazardous behaviours, such as smoking, alcohol consumption, loss of appetite, fatigue, and sleep difficulties [6, 7]. These risk factors are related to suicidal and nonfatal suicidal behaviors among university students [8]. Acculturative stressors and pressures [9] have negative consequences in terms of reduced mental health and students' LS [10]. Life dissatisfaction has a long-term effect on the risk of suicide, which seems to be partly mediated by poor health behaviours [11]. Social and familial pressures push postgraduates to join mobility aboard because they expect the outcome to be beneficial to their future careers, such as building an international social network. In the health field, an increased interest in an active social network (also known as social capital) has been explored, and suggests that social capital is positively related to health [12].

The expansion of knowledge about other cultures in order to gain competitive advantage in the international labor market has propelled young people to study not only in other European countries, but also in other regions of the world [13]. The experiences of mobility abroad are likely to enhance students' career prospects in terms of securing higher job interview rates, job offers and accelerating career progression [14, 15]. The employability of young graduates is increasingly dependent upon their ability to maintain 'positional advantage' and to acquire skills and behaviours appreciated in a labour market [16], for instance, autonomy and adaptability. These acquired competences can be explained in terms of social and cultural capitals, whose potential effects on health have been studied $[12,17]$. For instance, three levels of cultural capital that could offer a conceptual framework through which to explain student mobility have been identified: Institutionalized (educational credentials, specialized knowledge, etc.), embodied (personality, skills, etc.), and objectified (clothes, other belongings, etc.) [17]. Other studies emphasize a negative value of foreign cultural capital, stressing that local cultural capital may be more functionally relevant $[18,19]$. Similarly, reports about students' LS, before and after their mobility, and the effects of mobility on LS have also been mixed, with some suggesting a positive effect, others a negative effect, and others still, no effect at all [20]. Factors such as cultural empathy, social initiative, intercultural competences, language ability, knowledge about the host country, number of friends, satisfaction with finances, all of which intervene on LS, could explain these differences [21, 22].

Students who decide to study abroad differ from those who undertake their studies in their home country [23]. Embodied cultural capitals such as career attitudes may be represented by an individual's predisposition to employ competences and knowledge related to employability, acquired during their education. Students with a higher dynamic career attitude are more likely to identify future job opportunities more easily, by adapting their competences to the post-university transition [24]. Students may feel more comfortable managing and controlling important aspects of their lives and are more likely to be satisfied with their achievements [25].

International students may experience cultural shock and academic cultural shock. The gap between cosmopolitan versus local types is documented in the literature, with 'locals' described as disposing of stronger local interconnections or social capital, whereas 'cosmopolitans' are obliged to compete in an open competitive society, where they have to develop their own mobile capital (degree, skills, and resources). It can be argued that the former prefer the protection of communities (family, neighbourhood, etc.) while the latter search for stimulation and personal development in demanding contexts, potentially risky for health and cognitive resources [26-28]. However, in this competitive context, the exploration of LS for the local/non-mobile and for the mobile/cosmopolitan postgraduates and its determinants has been little investigated.

Between 1971 and 2011, the number of higher education students in the world increased five-fold, an upward trend that persists to date. Between 2000 and 2011, the number of foreign students enrolled in tertiary education doubled. The same trend is mirrored in Organization for Economic Co-operation and Development (OECD) countries as well. As a result, over the past two decades, the profile of tertiary education students and graduates has included more international students, and the preferred fields of study have changed. Accordingly, universities are introducing new programs as they are challenged to adapt 
their programs not only to the global economy, but also to the interests and priorities of the growing and diverse student population [29]. This may reflect the competitive nature of the labor market. Our contribution would allow universities to address the barriers to a successful graduate experience for both mobile and non-mobile students. Ultimately, interventions should be designed, evaluated, and the most promising implemented on a large scale. There is a growing need to explore the implications and to better understand the effects of mobility on postgraduates in various sociocultural and pedagogical situations. The aims of this study were to analyze the associations between LS and health-related factors, career attitudes and socioeconomic characteristics, and to determine factors that contribute to LS among mobile intra EU, mobile outside EU and non-mobile postgraduates who study in Luxembourg.

\section{Methods}

\section{Population and design}

A cross-sectional survey was conducted among the postgraduates who received financial aid from the government of Luxembourg, regardless of their socioeconomic situation. Registered in the database for the Centre de Documentation et d'Information sur l'Enseignement Supérieur (CEDIES), 644 postgraduates were invited to participate in this survey, organized independently of the university.

\section{Procedure and ethical consideration}

Students were contacted via an information flyer that was sent to their home addresses, inviting them to participate in a web survey. The flyer contained instructions about the goals of the study and the link to the selfadministered survey. Consent was obtained from the respondents before the survey.

\section{Instruments and their translation}

Participants could directly access the anonymous online questionnaire in either French or English. This had been translated and back-translated, and proofread by nativespeaking professional translators.

\section{Data collection}

\section{Three groups of variables were collected:}

* Life Satisfaction (LS) Dependent variable, (one item, how would you rate your life satisfaction? from 1 very dissatisfied, to 10 very satisfied), partially verbal labels (endpoints). This metric does not include a neutral midpoint answering option [30, 31]. Satisfaction with one's own life has been the focus of many cross sectional and longitudinal studies in the past decade, both within and across countries (OECD and Eurofound reports) [30, 31]. The most commonly used measures of life, evaluate 'life as a whole' or other similar over-arching constructs such as 'Overall LS' [31-33]. In addition to global judgments of life as a whole, it is also possible for people to provide evaluations of particular aspects of their lives (such as health or work) [34]. A strong relationship between overall life evaluations and evaluations of particular aspects of life exists. A meta-analysis [35] demonstrated that the asymptote for multiple item measures was the same as for single-item measures.

\section{Additional variables:}

* Health-related factors

- Health satisfaction (one item, Are you satisfied with your health? ranging from 1 very dissatisfied to 5 very satisfied) [30].

- Quality of life autonomy, a domain of the WHOQOL-BREF scale [36], QoL- autonomy (four items, from 1 strongly disagree to 5 strongly agree I have the freedom to make my own decisions; I feel control over my future; People around me are respectful of my freedom; I am able to do things I'd like).

- Worry was measured with the Penn State Worry Questionnaire [37] (three items from 1 not at all typical, to 5 very typical of me - Many situations make me worry; Once I start worrying, I cannot stop; I worry all the time).

* Career attitudes Four dimensions exploring attitudes [38] scored from 1 strongly disagree to 5 strongly agree.

- Career adaptability (four items, i.e. I am good at adapting to new work settings; I can adapt to change my career plans; I can overcome potential barriers that may exist in my work; I can adapt to change in the world of work);

- Career optimism (four items, i.e. I get excited when I think about my career; I understand- my workrelated interests; I am unsure of my future career success; I am eager to pursue my career dreams);

- Career knowledge (two items, i.e. I am good at understanding job market trends; It is easy to see future employment trends);

- Career planning (three items, i.e. I have been thinking a lot about the type of job that best fits me; I have a clear plan for my career in the forthcoming years; I have been thinking a lot about what I want to realize in my job during the forthcoming years).

* Socioeconomic characteristics Age, sex, type of household (living alone/not) and perceived financial situation (1 very bad to 6 very good). 


\section{Statistical analysis}

Three groups were compared: postgraduates studying only in Luxembourg, mobile intra EU and mobile outside EU. To explore the associations between LS and sociodemographic variables, health-related factors and career attitude factors, student's t-tests and bivariate correlations were used separately for each group. We estimated a single multiple regression model (Ordinary Least Squares) on the entire sample. We introduced the independent variable in interaction with the group variable to estimate each effect within each group of students. Only significant variables $(p<0.05)$ for at least one group were selected as explanatory variables. All scores were rescaled from one to 10 in order to make the estimated coefficients comparable. The analyses were performed using SPSS 22.0 software.

\section{Results}

Of the 644, 490 respondents had indicated their country of study, and were included in the survey. The sample consisted of three groups: mobile outside EU $(n=43)$, intra EU $(n=381)$ university and non-mobile $(n=66)$.

\section{LS indicators and socioeconomic characteristics (Table 1)}

Postgraduates who moved outside the EU (were mostly men and $63.2 \%$ of this group did not live alone) reported the highest LS. Intra EU and non-mobile groups were in majority women (57.8 and $51.6 \%$ respectively), and 64.3\% (intra EU) vs. 93.7\% (non-mobile) were not living alone. The non-mobiles who were studying in Luxembourg were the oldest group. For the outside EU group, autonomy of life, career adaptability and optimism scores were higher than for the other two groups. In contrast, planning and knowledge career attitudes were highest for the non-mobile.

\section{The relationships between LS scores and other variables (Table 2)}

For outside EU, only the financial situation and all health-related factors were linked to LS. For intra EU, their financial situation was positively related to LS. All health-related factors and career adaptability, optimism and planning were also positively linked to LS Only worry, was negatively associated $(-0.426)$. For the nonmobile, health satisfaction, and career optimism and planning were positively linked to LS.

\section{Associations between LS score and other variables, for each group (Table 3 )}

Multiple OLS regression was used to determine the associations between life satisfaction and other variables. For all groups, health satisfaction was positively linked with LS. This association was strongest for the outside EU group, for whom it was moreover the only determinant contributing to LS. Besides health satisfaction, for intra EU mobiles, autonomy and career adaptability were positively associated to the LS score (regression parameter estimates (b): 0.210 and 0.119 , respectively), and negatively to worry (b: -0.153$)$. For the non-mobile, career optimism and planning were also linked to their LS (b: 0.400 and 0.212 , respectively).

Table 1 Description of LS scores, socioeconomic, health-related factors and career attitudes, for each group

\begin{tabular}{|c|c|c|c|c|c|}
\hline \multicolumn{6}{|c|}{ Life Satisfaction $[1-8,12,17]$} \\
\hline & & Mobile outside EU = 43 & Mobile intra EU = 381 & Non mobile $=66$ & \\
\hline & & $\%$ or Mean (SD) & $\%$ or Mean (SD) & $\%$ or Mean (SD) & $p^{1}$ \\
\hline & & $8.5(1.5)$ & $7.8(1.6)$ & $7.9(1.5)$ & $0.043^{*}$ \\
\hline Age & & $27.4(8.1)$ & $26.6(5.2)$ & $31.0(8.5)$ & $<0.001^{* * *}$ \\
\hline \multirow[t]{2}{*}{ Sex } & Male & 63.2 & 42.2 & 48.4 & \multirow[t]{2}{*}{$0.038^{*}$} \\
\hline & Female & 36.8 & 57.8 & 51.6 & \\
\hline Type of household & Not living alone & 57.9 & 64.3 & 93.7 & $<0.001^{* * *}$ \\
\hline Financial situation & {$[1-8,12,17]$} & $7.4(2.7)$ & $6.7(2.2)$ & $6.8(2.3)$ & 0.157 \\
\hline \multirow{3}{*}{$\begin{array}{l}\text { Health-related } \\
\text { factors }[1-8,12,17]\end{array}$} & Health satisfaction & $7.9(2.0)$ & $7.4(2.2)$ & $7.4(2.3)$ & 0.438 \\
\hline & QoL-autonomy & $7.5(1.3)$ & $6.8(1.6)$ & $6.9(1.6)$ & 0.052 \\
\hline & Worry & $3.8(2.4)$ & $4.1(2.4)$ & $4.4(2.4)$ & 0.486 \\
\hline \multirow{4}{*}{$\begin{array}{l}\text { Career attitudes } \\
{[1-8,12,17]}\end{array}$} & Adaptability & $8.1(1.1)$ & $7.5(1.4)$ & $7.8(1.6)$ & $0.012^{*}$ \\
\hline & Optimism & $7.8(1.4)$ & $7.1(1.6)$ & $7.1(1.5)$ & $0.034^{*}$ \\
\hline & Knowledge & $5.7(2.1)$ & $5.6(2.3)$ & $6.0(2.4)$ & 0.440 \\
\hline & Planning & $6.4(2.1)$ & $6.5(2.3)$ & $6.6(2.0)$ & 0.772 \\
\hline
\end{tabular}

${ }^{1}$ Significant $p$-value: ${ }^{*} \mathrm{p}<0.05 ;{ }^{* *} p<0.01 ;{ }^{* * *} p<0.001$ are presented in bold 
Table 2 Relationships between LS and socioeconomic, health factors and career attitudes for each group

\begin{tabular}{|c|c|c|c|c|c|c|c|}
\hline \multicolumn{8}{|c|}{ Life Satisfaction $[1-8,12,17]$} \\
\hline & & \multicolumn{2}{|c|}{ Mobile outside EU } & \multicolumn{2}{|c|}{ Mobile intra EU } & \multicolumn{2}{|l|}{ Non-Mobile } \\
\hline & & Mean $(S E)^{1}$ & $p^{2}$ & Mean $(\mathrm{SE})^{1}$ & $p^{2}$ & Mean $(\mathrm{SE})^{1}$ & $p^{2}$ \\
\hline \multirow[t]{2}{*}{ Sex } & Male & $8.50(0.28)$ & 0.888 & $7.77(0.12)$ & 0.467 & $8.19(0.23)$ & 0.255 \\
\hline & Female & $8.43(0.45)$ & & $7.90(0.11)$ & & $7.76(0.30)$ & \\
\hline \multirow[t]{3}{*}{ Type of household } & Living alone & $8.75(0.17)$ & 0.334 & $7.71(0.15)$ & 0.207 & $7.50(0.29)$ & 0.586 \\
\hline & Not living alone & $8.27(0.40)$ & & $7.93(0.10)$ & & $7.93(0.20)$ & \\
\hline & & $\begin{array}{l}\text { Correlation } \\
\text { coefficient }^{3}\end{array}$ & $p^{2}$ & $\begin{array}{l}\text { Correlation } \\
\text { coefficient }^{3}\end{array}$ & $p^{2}$ & $\begin{array}{l}\text { Correlation } \\
\text { coefficient }^{3}\end{array}$ & $p^{2}$ \\
\hline Age & & -0.238 & 0.188 & 0.252 & 0.337 & 0.188 & -0.238 \\
\hline Financial situation & {$[1-8,12,17]$} & 0.366 & $0.024^{*}$ & 0.117 & $0.026^{*}$ & 0.223 & 0.084 \\
\hline \multirow{3}{*}{$\begin{array}{l}\text { Health factors } \\
{[1-8,12,17]}\end{array}$} & Health satisfaction & 0.609 & $<0.001^{* * *}$ & 0.437 & $<0.001^{* * *}$ & 0.439 & $<0.001^{* * *}$ \\
\hline & QoL-Autonomy & 0.334 & $0.038^{*}$ & 0.429 & $<0.001^{* * *}$ & 0.238 & 0.054 \\
\hline & Worry & -0.316 & $0.050^{*}$ & -0.426 & $<0.001^{* * *}$ & -0.140 & 0.261 \\
\hline \multirow{4}{*}{$\begin{array}{l}\text { Career attitudes } \\
{[1-8,12,17]}\end{array}$} & Adaptability & 0.157 & 0.340 & 0.321 & $<0.001^{* * *}$ & -0.037 & 0.767 \\
\hline & Optimism & 0.139 & 0.399 & 0.388 & $<0.001^{* * *}$ & 0.418 & $<0.001^{* * *}$ \\
\hline & Knowledge & -0.061 & 0.711 & 0.101 & 0.052 & 0.197 & 0.114 \\
\hline & Planning & 0.105 & 0.524 & 0.152 & $0.003^{* *}$ & 0.366 & $0.002^{* *}$ \\
\hline
\end{tabular}

${ }^{1}$ Std. Error; ${ }^{2}$ Significant $p$-value: ${ }^{*} p<0.05 ;{ }^{* *} p<0.01 ;{ }^{* * *} p<0.001$ are presented in bold; ${ }^{3}$ Pearson's correlation

\section{Discussion}

Our main findings show that the farther the mobility, the higher the LS. For all groups, the better the health satisfaction was, the higher the LS; confirming that health is a relevant indicator of LS [11]. In addition, autonomy and worry factors as well as career attitudes, i.e. adaptability, career optimism (aspirations) and planning explain some associations with LS. Mobility and LS highlight the contrast between local students (who present lower LS but higher optimism and planning) and cosmopolitan students (who present higher adaptability and LS). Below, we discuss the situation for each group.

For mobile outside-EU postgraduates, health satisfaction is the only determinant contributing to LS. Hence, all they need is to keep up their health situation to enhance their LS, which is necessary for their subsequent professional steps. European reports have identified perceived health status as the most notable predictor of LS [31], as well as an important component of overall well-being [30]. This major finding concurs with the fact that LS is related to positive outcomes as people who are satisfied with their lives, report lower levels of distress, which is predictive of future psychological behaviors $[39,40]$. Students in mobility capitalize on their competencies, knowledge and their sociocultural development [18]. These mobile students may embody traits that are desirable in the labor market, e.g. language skills or cultural familiarity: 'an overseas educational experience is believed to indicate (in its bearer) fluency in the English language as well as less obvious qualities, such as confidence, sociability, cosmopolitanism and possession of valuable social capital' [41]. During their study period in a foreign country, students have to change their living habits, adapt to the host country's conditions, adjust their professional goals to the labour market trends and develop their career attitudes further, to find a job [23].

For mobile intra EU graduates, the better their healthrelated factors (less worry, autonomy of life and health satisfaction) and the higher their career adaptability, the better their LS. International students have to cope with the financial and socio-cultural needs and psychological autonomy related to adjustment to the host country [21]; it is necessary to understand how they manage to turn a seemingly difficult situation into satisfying adaptation $[42,43]$. The experience abroad permits the acquisition of new skills and competences. Consequently, they may feel more confident in their abilities and professional prospects and believe they made the right career choice, which would guarantee an interesting job. Studying abroad has been shown to cultivate the development of a positive set of values (self-esteem, self-efficacy and feeling useful) and lead to the acquisition of attributes which are important once in the labour market $[15,44$, 45]. In contrast, the reverse may also be true, namely that self-selection among the more apt/ambitious students leads them to choose to study abroad - which leads to better outcomes among this group. Today, postgraduates must be able to manage the transition from their home country to their new country and to cope with obstacles related to their academic curriculum and their student life (psychological difficulties, socioeconomic circumstances, 
Table 3 Multiple regression to determine the associations between health-related factors, career attitudes and LS, for each group

\begin{tabular}{|c|c|c|c|c|c|c|}
\hline \multicolumn{7}{|c|}{ Life satisfaction $[1-8,12,17]$} \\
\hline & & $b^{1}$ & $\mathrm{SE}^{2}$ & ${\mathrm{~L} 95^{3}}^{3}$ & U95 ${ }^{4}$ & $p^{5}$ \\
\hline \multicolumn{7}{|l|}{ Mobile outside EU } \\
\hline Financial situation & {$[1-8,12,17]$} & 0.037 & 0.087 & -0.133 & 0.208 & 0.669 \\
\hline \multirow[t]{3}{*}{ Health-related factors } & Health satisfaction & 0.368 & 0.120 & 0.132 & 0.603 & $0.002^{* *}$ \\
\hline & QoL-Autonomy & 0.305 & 0.253 & -0.192 & 0.802 & 0.228 \\
\hline & Worry & -0.159 & 0.098 & -0.351 & 0.033 & 0.104 \\
\hline \multirow[t]{3}{*}{ Career attitudes } & Adaptability & -0.026 & 0.236 & -0.489 & 0.437 & 0.912 \\
\hline & Optimism & 0.008 & 0.193 & -0.372 & 0.388 & 0.967 \\
\hline & Planning & 0.064 & 0.134 & -0.200 & 0.328 & 0.634 \\
\hline \multicolumn{7}{|l|}{ Mobile intra EU } \\
\hline Financial situation & {$[1-8,12,17]$} & 0.040 & 0.032 & -0.022 & 0.102 & 0.209 \\
\hline \multirow[t]{3}{*}{ Health-related factors } & Health satisfaction & 0.193 & 0.033 & 0.129 & 0.257 & $\leq 0.001^{* * *}$ \\
\hline & QoL-Autonomy & 0.210 & 0.055 & 0.102 & 0.318 & $\leq 0.001^{* * *}$ \\
\hline & Worry & -0.153 & 0.031 & -0.213 & -0.092 & $\leq 0.001^{* * *}$ \\
\hline \multirow[t]{3}{*}{ Career attitudes } & Adaptability & 0.119 & 0.054 & 0.014 & 0.224 & $0.027^{*}$ \\
\hline & Optimism & 0.084 & 0.057 & -0.028 & 0.197 & 0.141 \\
\hline & Planning & -0.004 & 0.034 & -0.070 & 0.062 & 0.906 \\
\hline \multicolumn{7}{|l|}{ Non-mobile } \\
\hline Financial situation & {$[1-8,12,17]$} & 0.100 & 0.079 & -0.057 & 0.256 & 0.211 \\
\hline \multirow[t]{3}{*}{ Health-related factors } & Health satisfaction & 0.193 & 0.074 & 0.046 & 0.339 & $0.010^{* *}$ \\
\hline & QoL-Autonomy & -0.175 & 0.158 & -0.487 & 0.136 & 0.269 \\
\hline & Worry & -0.002 & 0.075 & -0.149 & 0.145 & 0.978 \\
\hline \multirow[t]{3}{*}{ Career attitudes } & Adaptability & -0.068 & 0.132 & -0.328 & 0.192 & 0.607 \\
\hline & Optimism & 0.400 & 0.147 & 0.112 & 0.689 & $0.007^{* *}$ \\
\hline & Planning & 0.212 & 0.095 & 0.026 & 0.398 & $0.026^{*}$ \\
\hline
\end{tabular}

${ }^{1} \mathrm{~b}=$ Parameter estimate; ${ }^{2} \mathrm{SE}=$ Standard error; ${ }^{3} \mathrm{~L} 95=$ Lower limit of the $95 \%$ confidence interval; ${ }^{4} \mathrm{U} 95=$ Upper limit of the $95 \%$ confidence interval;

${ }^{5} \mathrm{p}=$ Significance level of the $\mathrm{t}$-test: ${ }^{*} \mathrm{p}<0.05 ;{ }^{* *} \mathrm{p}<0.01 ;{ }^{* * *} \mathrm{p}<0.001$ are presented in bold

various socio-cultural relationships and additional requirements), which have an impact on their LS.

For the non-mobile group who pursued their studies in Luxembourg, in addition to health satisfaction as mentioned previously, their career optimism and planning attitudes were also determinants of LS. Their profile consisted of mainly women, who were also the oldest of the three groups of postgraduates (average age of 31 years) and the most likely to be living with family and to be working. A previous study among Luxembourgish native postgraduates [46] observed that higher health satisfaction, psychological quality of life and career optimism, were associated with higher LS. One hypothesis is that they saw themselves as leading a reasonably balanced lifestyle and they felt able to cope with their university studies. For our study postgraduates, the association between LS and the career attitudes (optimism and planning) showed that they possess local resources and social competences. Optimistic attitudes as the strongest determinant may imply that they believed their background gave them confidence in their knowledge in potential work sectors and/or tangible options for career advancement. In other words, under certain circumstances, as with the local postgraduates in our study, the incentives to stay in the home country, Luxembourg, may be higher as it allows building or increasing local cultural capital for getting ahead in(to) the home labor market. The importance of career planning attitudes seems to confirm their strategic motivation and rational focus on employability in their decision against mobility. In sum, this group seems to be at a different point in life where they have perspectives and strategic plans that may collide with spending time abroad. Additionally, in the international, multicultural and multilingual context of Luxembourg, much of the 'foreign cultural capital' may be accrued in the home country [47].

Contextualizing our results, general LS was higher for the postgraduates who studied overseas (8.5/10) compared to those who were mobile intra EU (7.8/10) and those who were non-mobile (7.9/10). The mobile outside EU were 
mostly men and 2/5 did not live alone. The non-mobile group who studied in Luxembourg was on average older and the majority did not live alone. Several explanations could be given for their stay. They were unable to stay in their own countries; probably lived as part of a couple or in a family with or without children. This likely means that they were possibly taking care one or more family member/s or they worked part time. The same reasons could be proposed for the mobile intra EU because mobility abroad can be achieved in the countries bordering Luxembourg, as it is easy to commute daily to and from home. It is notable that for the postgraduates outside EU (25-34 years), LS was higher than the national LS indicator in Luxembourg (7.7/10 in 2013). However, in our study, the scale was scored from 0 to 10 , which gave a value of 7.93/ 10 when scored to from 1 to 10 . In the EU-28, the score was 7.3/10 in 2013 - scored from 0 to 10; and 7.53 when scored from 1 to 10, for the same age group [48]. Another result from our study revealed that a correlation between LS and financial situation exists only among the mobile postgraduates. This finding confirms previous research [21] which pointed out that satisfaction with one's financial situation is an important factor in predicting subjective well-being and which affects their LS, though no such link was found among the nonmobile university students.

\section{Strengths and limitations of our study}

The main strength of the present study was the recruitment of a population of students legally residing in Luxembourg, who could pursue their Master's degrees all over the world, thanks to the financial aid from the Luxembourgish government. Further, within the mobility, two types of students were identified (a) those who chose to go and (b) those who had no choice but to go. In the first case, they decided to study abroad in pursuit of their own interests; in the second case, they had to move, given that Luxembourg's small size and young university did not locally offer their desired academic programs or courses.

As the OLS model was estimated on the entire sample, a common residual variance was estimated, which made it possible to maintain a reasonable power of the tests, in comparison with the adjustment of a distinct regression model for each group separately. Nevertheless, the low number of observations in the mobile outside EU group and the non-mobile group remains a limit which decreased the precision of the parameters estimated for these two groups. In other words, small effect sizes were more difficult to detect with fewer observations, increasing the risk of falsely confirming the null hypotheses.

\section{Conclusions}

Mobile postgraduates possess a superior cultural capital gained through their higher adaptability and autonomy, suggesting that Bourdieu's concept of cultural capital is a part of the social inequities puzzle. Thus, more research on the effects of cultural capital on LS and health is necessary. Furthermore, we recommend that LS among mobile and local students be measured periodically in all universities. Enhancing postgraduate students' LS through cultural accompaniment, provision of counseling and orientation programs needs to be proposed by the host universities, to reduce inequality gaps.

In terms of cultural capital's utility in health promotion, this study suggests that, in addition, university policy makers need to address health inequities and how its different elements may influence LS. Health promotion needs to promote an empowerment approach with a focus on student community mobilization that complements social initiatives. The challenge faced by universities, is to design strategies that will help students, especially the locals, to develop a 'portfolio of resources', linking them to a wealth of resources.

\section{Abbreviations}

CEDIES : Centre de Documentation et d'Information sur l'Enseignement Supérieur; Intra EU: Students who pursue part of their studies (example, Erasmus semester) in a European country, different that their home country Luxembourg; LS: Life satisfaction; Outside EU: Students who study a part of their courses (example, Erasmus global exchange) out of the European countries; QoL: Quality of life

\section{Acknowledgments}

Our thanks to all the volunteers and two scientific collaborators (Senad KARAVDIC \& Chrysoula KARATHANASI) without whom this research would not have been undertaken, and to Centre de Documentation et d'Information sur l'Enseignement Supérieur (CEDIES) from the Grand-duchy of Luxembourg for their technical help.

\section{Authors' contributions}

AO: Conducted the art of the literature, the data analysis, conceived the interpretation of the findings and drafted the manuscript; LC: Participated in reviewing the literature, in conceiving of the interpretation of the findings and in drafting of the manuscript; $\mathrm{AH}$ : participated in conceiving the interpretation of the findings and in reviewing the manuscript; ELB: Conducted and reviewed the statistical analyses; MB: Conceived the study and the protocol, secured the funding to conduct the research, conducted the art of the literature, the interpretation of the findings, and took a lead role in drafting the manuscript. All authors read and approved the final manuscript and consent to publication in this review.

\section{Funding}

The project 2013-2017 entitled 'CAPJOB' was supported by a financial grant from the University of Luxembourg N ${ }^{\circ}$ R-AGR-0278-10.

\section{Availability of data and materials}

Data and material are available at the Ethics Committee of the Institute for Research on Socio-Economic Inequalities, axis Health Inequalities.

\section{Ethics approval and consent to participate}

The research protocol adhered to the principles outlined in the Declaration of Helsinki and was pre-approved by the direction of the Centre de Documentation et d'Information sur l'Enseignement Supérieur (CEDIES) and approved by the Ethics Committee of the Institute for Research on Sociology \& Economic Inequalities. Postgraduates participating in the survey were informed of the study objectives and signed a consent form.

Consent for publication

Not applicable. 


\section{Competing interests}

The authors declare that they have no competing interests.

Received: 16 May 2019 Accepted: 7 November 2019 Published online: 06 January 2020

\section{References}

1. Bhandari P. Stress and health related quality of life of Nepalese students studying in South Korea: a cross sectional study. Health Qual Life Outcomes. 2012;10(1):26.

2. Melin R, Fugl-Meyer KS, Fugl-Meyer AR. Life satisfaction in 18- to 64-year-old swedes: in relation to education, employment situation, health and physical activity. J Rehabil Med. 2003:35:84-90.

3. Wang $Y$, Kong $F$. The role of emotional intelligence in the impact of mindfulness on life satisfaction and mental distress. Soc Indic Res. 2014; 116(3):843-52.

4. Diener E, Biswas-Diener R. Will money increase subjective well-being? A literature review and guide to needed research. Soc Ind Res. 2002;57:119-69.

5. Diener E, Ng W, Harter J, Arora R. Wealth and happiness across the world: material prosperity predicts life evaluation, whereas psychosocial prosperity predicts positive feeling. J Pers Soc Psychol. 2010;99:52-61.

6. Ionescu I, Spitz E, Bucki B, Baumann M. Physical and mental health, substance abuse and preventive behaviour: disparities between central/ eastern versus Western European first-year university students in social sciences. Analele Stiintifice ale Universitatii "Alexandru loan Cuza". Sectiunea Sociologie si Asistenta Sociala - Scientific Annals of the "Alexandru loan Cuza" University. Sociology and Social Work Section. 2014;7(1):96-115.

7. Baumann M, lonescu I, Chau N. Psychological quality of life and its association with academic employability skills among newly-registered students from three European faculties. BMC Psychiatry. 2011;11:63-72.

8. Eskin M, Sun JM, Abuidhail J, Yoshimasu K, Kujan O, Janghorbani O, Flood C, Carta MG, Tran US, Mechri A, Hamdan M, Poyrazli S, Aidoudi K, Bakhshi S, Harlak H, Moro MF, Nawafleh H, Phillips L, Shaheen A, Taifour S, Tsuno K, Voracek M. Suicidal behavior and psychological distress in university students: a 12-nation study. Arch Suicide Res. 2016;20(3):369-88.

9. Hamaideh SH. (2011). Stressors and reactions to stressors among university students. Int J Soc Psych. 2011;57:69-80.

10. Pan J, Fu D, Wong K, Joubert L, Lai C, Chan W. The protective function of meaning of life on life satisfaction among Chinese students in Australia and Hong Kong: a cross-cultural comparative study. J Am College Health. 2008;57(2):221-31.

11. Koivumaa-Honkanen H, Honkanen R, Viinamäki H, Heikkilä K, Kaprio J, Koskenvuo M. Life satisfaction and suicide: a 20-year follow-up study. Am J Psychiatry. 2001;158:433-9.

12. Ferlander $\mathrm{S}$. The importance of different forms of social capital for health. Acta Sociologica. 2007;50:115-28.

13. OECD. Indicator C4: Who studies abroad and where? Education at a Glance 2014: OECD indicators, no. Ccc: 1-497. [doi:https://doi.org/10.1787/eag-2011-en].

14. Kimberly F. Long-term career impact and professional applicability of the study abroad experience. Frontiers: The Interdisc J Study Abroad. 2010;19:169-91.

15. Stroud AH. Who plans ( not ) to study sbroad? J Stud Int Educ. 2010;14(5):491-507.

16. Waters JL. In pursuit of scarcity: transnational students, 'employability', and the MBA. Environ Plan. 2009;41(8):1865-83.

17. Bourdieu P. The forms of capital. In Handbook for Theory and Research for the Sociology of Education. Ed. Richardson, JG (Greenwood Press, Oxford) 1986: $241-258$

18. Sin IL. Cultural capital and distinction: aspirations of the 'other' foreign student. Br J Sociol Educ. 2013;34:848-67.

19. Brooks R, Waters J, Pimlott-Wilson H. 2012. International education and the employability of UK students. Br Educ Res J 2012; 38(2): 281-298.

20. Nilsson A. Life satisfaction among outbound students in northern Sweden. World J Educ. 2015;5(4):87-92.

21. Lackland SD. Satisfaction with life among international students: an exploratory study. Soc Ind Res. 2001;53:315-37.

22. Young TJ, Sercombe PG, Sachdev I, Naeb R, Schartner A. Success factors for international postgraduate students' adjustment: exploring the roles of intercultural competence, language proficiency, social contact and social support. Eur J Higher Educ. 2013;3(2):151-71.

23. Waldinger F, Parey M. Studying abroad and the effect on international labor market mobility. Econ Journal. 2011;121(551):194-222.

24. Mel F, Kinicki AJ, Ashforth BE. 2004. Employability: a psycho-social construct, its dimensions, and applications. J Voc Behav 2004; 65(1): 14-38.
25. Judge T. Core self-evaluation and work success. Curr Directions Psycho Sc. 2009;18(1):58-62.

26. Merton R. Patterns of influence: local and cosmopolitan influentials. In: Lazarsfeld P, Stanton F, editors. Communications in research. New York: Harper Brothers; 1949. p. 180-219.

27. Weenink D. Cosmopolitanism as a form of capital: parents preparing their children for a globalizing world. Sociology. 2008;42(6):1089-106.

28. Igarashi $\mathrm{H}$, Saito H. Cosmopolitanism as cultural capital: exploring the intersection of globalization, education and stratification. Cult Sociol. 2014;8(3):222-39.

29. OECD. Education at a glance 2018: OECD indicators. OECD Publishing, Paris, 2018. [https://doi.org/10.1787/eag-2018-en].

30. OECD. Guidelines on measuring subjective well-being. OECD Publishing. 2013. ISBN 978-92-79-28315-4 (PDF). [https://doi.org/10.1787/9789264191655-en].

31. Eurofound. Quality of life in Europe: subjective well-being. Luxembourg: Publications Office of the European Union, 2013. ISBN 978-92-8971-120-3.

32. Kjeldstadli K, Tyssen R, Finset A, Hem E, Gude T, Gronvold N, et al. Life satisfaction and resilience in medical school - a six-year longitudinal, nationwide and comparative study. BMC Med Educ. 2006;6:48.

33. D'Ambrosio C. An overview of intertemporal measures of individual well-being: can they explain life satisfaction better? In T Toshiaki (Ed.) Advances in happiness research. A comparative perspective. Part of the creative economy book series (CRE). 2016; 20(1): 39-54. ISBN 978-4-431-55753-1.

34. Diener E, Emmons R, Larsen RJ, Griffin S. The satisfaction with life scale. J Pers Assesst. 1985:49(1):71-5.

35. Schimmack U, Krause P, Wagner GG, Schupp J. Stability and change of wellbeing: an experimentally enhanced latent state-trait-error analysis. Soc Indic Res. 2010;95:19-31.

36. Leplège A, Perret-Guillaume C, Ecosse E, Hervy MP, Ankri J, von Steinbüchel $\mathrm{N}$. [a new instrument to measure quality of life in older people: the French version of the WHOQOL-OLD]. La Rev. Médecine Interne. 2013:34(2):78-84.

37. Berle D, Starcevic V, Moses K, Hannan A, Milicevic D, Sammut P. Preliminary validation of an ultra-brief version of the Penn State worry questionnaire. Clin Psychol Psychother. 2011;18:339-46.

38. Karavdic S, Karathanasi C, Le Bihan E, Baumann M. Associations between psychoeducational determinants and dynamic career attitudes among undergraduate students. In C. Pracana (Ed.), Psychology Applications \& Developments - Advances in Psychology and Psychological Trends Series. Lisboa: In Science Press 2014 : 239-247 [http://orbilu.unilu/bitstream/10993/19452/1/PDA_Book.pdf].

39. Pavot W, Diener E. The satisfaction with life scale and the emerging construct of life satisfaction. J Positive Psychol. 2008;3:137-52.

40. Rojas M. Life satisfaction and satisfaction in domains of life: is it a simple relationship? J Happiness Stud. 2006;7:467-97.

41. Waters JL. Transnational family strategies and education in the contemporary Chinese diaspora. Global Networks. 2005;5:359-77.

42. Sam DL. Satisfaction with life among international students: an exploratory study. Soc Ind Res. 2001:53:315-37.

43. Chirkov VI, Vansteenkiste M, Tao R, Lynch M. The role of self-determined motivation and goals for study abroad in the adaptation of international students. Int J Intercul Relations. 2007;31(2):199-222.

44. Mohajeri NE, Gillespie J. How study abroad shapes global careers evidence from the united states. J Stud Int Educ. 2009;13(3):382-97.

45. Kimberly F. Long-term career impact and professional applicability of the study abroad experience. Frontiers: The Interdisc J Stud Abroad. 2010; 19(Fall):169-91.

46. Karathanasi C, Odero A, Baumann M. Factors that contribute to work satisfaction of masters students and graduates. In International Psychological Applications Conference and Trends. Edited by C Pracana and M Wang Portugal, Lisbon: World Institute for Advanced research and Science 2016: 65-69. [https://files.eric.ed.gov/fulltext/ED580800.pdf].

47. Murphy-Lejeune E. Student mobility and narrative in Europe. London: Routledge.2002. [http://journals.lub./u.se/index.php/st/article/view/3542/3121].

48. EUROSTAT Quality of life in Europe - facts and views - overall life satisfaction Statistics Explained. Luxembourg: Publications Office of the European Union, 2015.[http://ec.europa.eu/eurostat/documents/3217494/6856423/KS-05-14-073EN-N/742aee45-4085-4dac-9e2e-9ed7e9501f23].

\section{Publisher's Note}

Springer Nature remains neutral with regard to jurisdictional claims in published maps and institutional affiliations. 